\title{
Demography in Nigeria: Problems and Prospects
}

\author{
Etebong PC* \\ Department of Mathematics and Statistics, University of Uyo, Nigeria
}

Submission: November 25, 2017; Published: February 20, 2018

*Corresponding author: Etebong P Clement, Department of Mathematics and Statistics, University of Uyo, Nigeria; Email: epclement@yahoo.com

\section{Abstract}

This paper is set to examine demography in Nigeria, highlighting its problems and prospects. It discusses why the Nigerian population is increasing drastically and the possible implications of an unchecked rapidly growing Nigerian population. It suggests ways of solving the Nigerian demographic problems thus reducing its growth to pave way for the rapid socio-economic development and Government achievement in line with the Government realization of the Millennium Development Goals (MDGs).

Keywords: Demographic dividend; Millennium development goals; Population crash; Socio-economic development

Abbreviations: MDGs: Millennium Development Goals; CBR: Crude Birth Rate; DHS: Demographic and Household Surveys

\section{Introduction}

Demography is the study of both the quantitative and qualitative aspects of human population. Quantitative aspects include the composition, density, distribution, growth, movement, size and the structure of the population. The qualitative aspects are the sociological factors such as education quality, diet and nutrition, race, social class, crime, wealth and wellbeing. Thus, the demography of Nigeria offers you a clear analysis of the prevalent living condition in the country. Demography shows how people are distributed in the world by continent, countries, regions urban versus rural areas, or desert, native, foreigners and races. Population distribution depends on environment and the environment has a great deal to do with population density as well.

Nigeria has a high population growth and what can also be referred to as an increasing population. Nigeria is the most populous country in Africa and also the most populous among the black nations of the world. Globally, Nigeria is among the ten top countries with the largest population, in fact, the eighth most populous country in the world with approximately 162 million people [1]. Despite declining fertility, Nigeria's population is expected to continue to grow to 239 million by 2025 and 440 million by 2050 due to population momentum, making it then the 4th most populous country in the world [2]. Most of this growth will be people in the working ages, between age 15 and 64. Thus, the dependency ratio, or the number of children and elderly (under age 15 and over age 65) divided by the number of working age adults (between ages 15-64), will fall over this period from 88 dependents per 100 workers in 2010 to only 69 dependents per 100 workers by 2050 .

The median age of the total population is likewise anticipated to increase from 17.9 to 21.4 years over the 40 -year period from 2010 to 2050 [2]. These trends are of particular importance because Nigeria is expected to make up three percent of the total world population and 14 percent of Africa's population by 2050 [2]. Thus, Nigeria will be poised to be a major player in the global system, and particularly important in the African region. In addition to its valuable human capital, Nigeria's oil and gas resources represent a potential development boost. Nigeria contains 37 billion barrels of proven oil reserves and 5 trillion cubic meters of natural gas reserves [3,4]. It is already ranked among the top 13 oil producers globally [5]. Yet despite these tremendous resource advantages, Nigeria continues to lag behind on many development indicators [6-8]. Why? Primarily Nigeria has not properly invested in its current and future labour force, nor has it developed its oil and gas industries to produce long-term growth in both jobs and GDP, nor has it diversified its economy.

The economic growth potential posed by the demographic transition is created by a decline in mortality that precedes a large decline in fertility. This period of lower mortality and higher fertility, often known as a baby boom, will ultimately lead to a working age bulge or a potential demographic dividend when this large cohort of children grows up. However, whether the working age bulge constitutes a dividend or not also 
depends on the availability of employment. A country's dividend cannot be realized if there is widespread unemployment among its working age population. This is because those outside the labour force consume part of what is produced by the currently employed, and this influences the amount of surplus that is available for investment after consumption.

The population of Nigeria has a built-in potential for rapid growth through natural increase. Population of Nigeria is increasing rapidly. Rapidly increasing population may result due to the effect of three important factors. They are birth rate, death rate and higher net migration. Migration has played a negligible role in Nigerian population increase. If an increasing population is brought about as a result of an increase in birth rate, there will be higher percentage of young people and children in the population. However, if it is by a decrease in death rate, then, there will be an increase in the total number of old people in the population. Furthermore, if an increase in population is brought about as a result of a higher net migration, then, there will be a larger number of people between ages of 16 and 50 years. Nigeria population is increasing mostly due to the effect of the first factor, that is, high birth rate. For instance, Crude Birth Rate (CBR) was 39.0 and 44.6 in 1990 and 1991 respectively. It was 42.0 in 2003 . All these buttress the fact that there is high CBR in Nigeria. Nigerian population has gathered momentum. It will continue to increase for some time even if there is a change favourable towards family planning and birth control. Increasing population at the expense of socio-economic development is inimical to people's well-being and development. An increasing population has consequences and implications most especially for a country like Nigeria. This is the thrust of this paper.

\section{Why the nigerian population is increasing rapidly}

The major factor causing unprecedented growth of population in Nigeria is birth rate and this has affected greatly the growth rate of the population. According to the 2006 Population Census, the growth rate was 3.02. This shows that Nigerian population will double in less than 22 years. There are many factors that have generated increase in birth rate. In Nigeria, religions, superstitions and customs have encouraged population growth. Many religions in Nigeria promote large families with the encouragement of early marriage and polygamous family system while some prohibit the most effective forms of birth controls like the use of contraceptive and family planning. Early marriage tends to lead to high birth rate because women will have opportunity of having many children due to long child bearing/reproductive years. Many cultures in Nigeria highly valued the male child than the females for a variety of reasons: some for sustenance of family prestige; some for greater upper-body strength for physical labour in the farm or during war while some for old age social security. This male child preference leads to the common practice of continuous child birth in an attempt to have more male children.
Illiteracy rate is also worth mentioning as a factor in population growth in Nigeria. The summary of characteristics of the 2003 and 2008 Demographic and Household Surveys (DHS) samples on mean age and years of education shows that educational attainment in Nigeria remains low, and according to the 2006 Census, about 47 percent of the population is illiterate $[9,10]$. According to the 2008 DHS, about 36 percent of women have no formal schooling. The mean years of education appear to have decreased between the two DHS surveys, which indicate poor educational policy or poor data quality and implementation of programs. Again, according to the 2006 Census, the average household size is large, with over 72 percent of households having at least five people. Mean household size in the DHS surveys confirms this. Marriage is relatively universal in Nigeria and those who are widowed or divorced at younger ages often remarry.

It also shows that urban residents have higher levels of education than their rural counterparts. Sixty-nine percent of urbanites have secondary or higher levels of education, while only about 37 percent of rural dwellers do. This is not surprisingly because educational access is more difficult in rural areas, as there are fewer schools and fewer resources, in addition to the tradition that rural children are often kept from attending school to help with agricultural or home chores [11-13]. On average, women are much less educated than men. The high rate of literacy among the Nigerian populous and in particular among women posts a major problem to the Nigerian economy. Illiteracy brings poverty, diseases, insecurity, homelessness, unemployment; and general backwardness. Besides, high rate of illiteracy among the Nigerian women will increase the rate of teenage pregnancy that in turns increases the fertility rate which eventually leads to overpopulation.

Another critical factor is the inefficient national population policy. Given the upsurge in population growth rate and its attendant's implications on the nation's development indices, the Federal Government of Nigeria in1988 for the first time decided to formulate a national population policy for the country. Fifteen years after the enunciation of the 1988 population policy, the emergences of new activities and issues such as the 1991 National Population Census, 1994 International Conference on Population and Development, the 1999 HIV/AIDS summit in Abuja, poverty and food security and the population environment - development nexus issues make a revision of the National Population Policy necessary. Hence the policy was revised in 2004.The policy contains several goals and targets. Although it was recognized as a worthwhile endeavour, the policy lacks a lot of mends. First, there are no penalties in the policy for those who falsify population records during and after population census. This lacuna in the population documents has created a lee way for politicians to continuously engage in sharp practices during heads counts. This bring about the controversies surrounding 
the acceptance or otherwise of national population data. That is why population figures in Nigeria have been figment of official imaginations since independence in 1960.

Again the policy failed to state categorically the upper limits of a family size. A man can decide to have 4 children from each woman and marry 10 wives to have 40 children without being culpable before the law. Such a law is indeed hollow and of no significance in the struggle to reduce population and enhance social welfares for the citizenry. Another factor though not very significant is the increase in material well-being of some families. When people are materially well off, they give little thought to the number of children to have. Wealth has encouraged many people to have large families and thus result to high birth rate.

\section{Nigerian demographic problems and implications}

The national population policy recognizes population factors, social and economic development, and environmental issues as irrevocably entwined and are all critical to the achievement of sustainable development in Nigeria. Consequently, this section discusses the problems of demography in Nigeria and the possible implications of an unchecked rapidly growing population under the three recognized factors by the policy namely; the census, the environment and the economy.

The Census: Census-taking is a very sensitive issue that has remained intractable in Nigeria. A series of censuses makes it possible to appraise the past, accurately describe the present, and estimate the future. Since Nigeria attained independence in 1960, the population of each region or state has become an important yardstick for deciding how much of the country's annual earnings are allocated to the regions or states. The recorded size of the population of each state according to census data is, therefore, a crucial factor in determining, in political and economic terms, the relative importance of each state. It is, therefore, not surprising that the more literate persons as well as political leaders have become very interested in and enthusiastic about the political and monetary value of a census in Nigeria. Hence, at subsequent censuses after 1952-1953, they have tried to ensure not only that all their own people are counted but also that they are counted twice or more, if possible, in order to record as high a figure as possible. This unfortunate mixture of political and economic issues with population count has meant that no one can tell the number of Nigerians with any degree of accuracy. The situation has marred our planning and development efforts as a country.

The Environment: Population distribution depends on environment and the environment has a great deal to do with population density as well. Most population studies focus on the subjects of natality, mortality, migration, and resultant growth, which are then related to production and consumption. The environment, both the physical and cultural setting, influences elements of population growth, yet there have been few cases in which the effect of the environment on population is considered. Nigeria as a country should put into consideration the environment as a part of any plan, or policy on population study. In addition to growth, environmental factors are often responsible for the distribution and density of population. These factors cause some areas to remain unsettled while others are overpopulated. In the overpopulated areas in Nigeria, environmental degradation results when the capacity of the land to support the human and animal population is exceeded. The natural productivity of marginal lands in the tropics and subtropics often exceeds the yields presently obtained from using these lands for cultivation or animal husbandry. The impacts of the population crash in Nigeria on the environment are seen through land degradation and desertification, climate change and deforestation.

Land degradation and desertification: An increase in human population demands ever more resources and expands more and more over the landscape, leading to increased desertification. Desertification is a type of land degradation in which a relatively dry land region becomes increasingly arid, typically losing its bodies of water as well as vegetation and wildlife. Desertification is a significant global ecological and environmental problem of over population. Desertification causes:

o A high-risk of crop failure

o Low economic returns on crops

o A build-up of salt in the soil and

o An accidental burning of semi-arid vegetation

This process turns usable desert land into unusable land due to poor land management and has serious impacts on health namely:

o Higher threats of malnutrition from reduced food and water supplies;

o More water- and food-borne diseases that result from poor hygiene and a lack of clean water;

o Respiratory diseases caused by atmospheric dust from wind erosion and other air pollutants;

o The spread of infectious diseases as populations migrate.

Desertification also leads to extinction of species. Species that once lived in a more fertile and productive climate may not survive in a decertified region. With a changing ecosystem, species must adapt to their new climate, migrate to a more favourable climate, or they will go extinct. Also, desertification events have been a major driver behind the migration of large human populations throughout history.

Climate change: As humans continue to remove vegetation from landscapes, there is less remaining vegetation to add moisture to the soil that will evaporate into the air and form 
clouds that lead to rainfall. With significantly reduced rainfall, drought occurs and leads to a hotter and drier climate, and later causes desertification in the surrounding landscape.

Deforestation: Deforestation is the clearing of large parts of our forests for human needs. Forests are being cut down today to be used as fuel, for agriculture, timber harvesting, due to increasing human populations, war, and animal husbandry in dry lands. Once the trees and other vegetation in an area are gone, there is nothing left to hold the soil in place. The soil then turns to dust and can be blown and washed away, and the soil is degraded and the precious soil nutrients are lost, leaving the soil infertile and useless.

The Economy: The possible impact of the population crash in Nigeria on the economy is seen through rapid urbanization (rural-urban migration). The United Nations data [1] puts the percentage urban and rural population in Nigeria as at 2010 at 49.8 percent urban and 51.2 percent rural. It is also projected to increase quite rapidly, with over the half of the population living in urban areas by 2015 and over three-quarters of the population living in urban areas by 2050. In terms of growth, the UN estimates that the urban population in Nigeria is growing currently at a rate of about 3.75 percent, and it will continue to grow at a higher rate annually through 2025. Following from these projection rates, it is anticipated that the percentage of Nigeria's urban dwellers will increase while the percentage of rural dwellers will decrease over time. Addressing the needs of these increasing numbers of urban residents, including their access to food, housing, education, employment and services will be a major challenge for Nigeria's government in the coming decades and will be critical in harnessing the benefits of her demographic dividend.

Some of these new urban residents will be migrants from rural areas, so there will likely be additional challenges in integrating them into the cities[14], though some of them will be the children of current urbanites, as natural increase (fertility) according to Chen et al. [15], also contributes to urbanization and represents a greater share of urban growth in sub-Saharan Africa than it does in other regions, so these urban growth rates in Nigeria may likely capture relatively high urban fertility rates [16-21]. As a city grows, the cost of housing and infrastructure also grows, since there are less water, land and building material available, and greater congestion problems. As a city decays in this way, governments often do not meet the service needs of residents and urban development is dominated by private capital. Unemployment grows, as do drug abuse, crime and homelessness [22]. Most social amenities in Nigeria are in some states of decay and resources no longer cope with human population. Our social institutions are overcrowded and infrastructures are stretched to the limit. For instance, most of the universities in Nigeria built to accommodate a population of at most 6000 students are now accommodating at least 25,000 students. The markets are equally over crowded with stalls and make-shift stores by traders who desire to make a living while our roads in the cities are filled with hawkers of different wares. The roads, hospitals, libraries, housings and schools equally can no longer cope with the increasing human population.

\section{Prospects and recommendations}

Given the upsurge in population growth rate and its attendant's implications on the nation's development indices as discussed above, this section suggests ways of solving the Nigerian demographic problems in order to pave way for the rapid socio-economic development and Government achievement in line with the Government realization of the Millennium Development Goals (MDGs).

The Census: Nigerian leaders and planners need to realize the importance of census data as the basic ingredient in any plans for the future development of the country. Here, three suggestions to overcome the problems pertaining to census taking in Nigeria are proposed. Firstly, a good population policy is expected to go along with a set of socio-economic responsibility packages towards the citizenry. These socio-economic rights for the aged in particular will provide old age social security for them and discourage the dependence on one's offspring and family members for care and support at old age. So the national population policy should inculcate in it the creation of such rehabilitation and reformatory centres in subsequent review. It is recommended that the National Population Policy of 2004 should be reviewed in line with global setting or a well defined new National Population Policy is formulated for the country.

Secondly, there should be an establishment of a system for collecting vital statistics. Change in the population is the outcome of events like births, deaths, migration, marriages, divorces, and so on, called vital events. Therefore, vital statistics are those data concerned with vital events. Vital statistics can be obtained from census data, while the composition of population may be derived from vital events [23]. Vital statistics enable planners to update census figures in those years when no census is taken. In developed countries, registration of the occurrence and characteristics of these events is compulsory so that permanent records and vital statistics are available. The processes of compiling adequate statistics, from registration forms are similar to those required for census statistics. It is recommended that Nigeria should have a universal and useful vital statistics system. Vital registration centres should be set up all over the country and registration of vital events should be made compulsory for all. Provision of family planning services should be encourage because, improved family planning reduces the number of children to be cared for, thereby increasing the resources available to investing in each child's health, education and other social needs.

Child birth restriction should be advocated. For instance, in order to check rapidly growing population, China place child birth at one child birth per family. This child birth restriction will disabuse the male child preference syndrome in Nigeria. Also, couples with number of children above the official figure 
specified by a well defined National Population Policy should be made to pay taxes per head of extra number of children. These measures will go a long way to curb over population. Thirdly, the revenue allocation formula for the disbursement of funds from the federation account to states and local government councils in Nigeria should be reviewed. The formula gives much emphasis to a large population size. As a result of these financial gains, census figures have in the past been inflated by nearly all segments of the country. In fact, an economic factor that affects the success of policy reforms is the distribution of revenue $[24,25]$. Census figure are used to determine regional funding and representation of ethnic and regions groups in government services in Nigeria. This provides an incentive for inflating local population. It is recommended that emphasis in the distribution of revenue should be shifted from a large population size to specific economic and social needs and programs aimed at improving the quality of life of the people concerned.

The Environment: An adequate survey of arable lands and the natural productivity of the various biomes for all the country are required. A program should be instituted to encourage the settlement of those fertile areas now unoccupied or sparsely occupied for social, historical, or traditional reasons. The present technology used to cultivate various areas in the country is inadequate, often nearly primitive, and does not reflect the potential productive capacity of the land. More advanced technology would provide substantially increased yields which could support an increased number of people. In this task, the nation should take note of man's role as a producer as well as his role as consumer since equilibrium between these two functions has always been an important goal of development. Government need to explore and evaluate our natural resources. We should also diversify our economic resources and supplement them with some measure of industrialization. Malnutrition, inadequate health and sanitary facilities, and illiteracy, as well as certain social factors, are the real causes of poverty and backwardness. The government should try to increase the life expectancy of their population and the productivity of their manpower. Modern technology is needed to increase the skills of the population. These measures go hand in hand with increasing the capability of the land to sustain a better-fed, better-equipped, and more productive population.

The Economy: The growth rate of the population needs to be studied, monitored and managed properly with conscious efforts. If not, it can militate against all the efforts of government to fulfil its commitment to improving the quality of live and standard of living of the people of the country. To achieve the following goalssustained economic growth, poverty eradication, protection and preservation of the environment, and provision of qualify social services, balance between the rate of population growth, available resources, and the social and economic development of the country and complete demographic transition to a reasonable growth in birth rates and low death rates and also that of Millennium Goals, population management is desirable. Nigeria is suffering from wide spread poverty and rising unemployment. Moreover, there is mass movement of people from rural areas to urban areas thereby creating many social vices. This is because the available industries cannot afford to employ the growing number of labour force. For Nigeria to turn the tide of its economic misfortunes and mismanagement, it will have to take steps to raise domestic food production, labour productivity, reduction of absolute poverty, lower population growth among many other things. For the health of mother, child and welfare of the family, population growth should be monitored and regulated. Healthy family can help in socioeconomic development while an unhealthy family is a liability to the government and society. It is also inimical to economic growth and development of the nation and the world at large.

\section{Conclusion}

Nigerian population is growing rapidly without corresponding growth in socio-economic development. According to Thomas Malthus an increasing population without corresponding increase in the means of subsistence will breed poverty, diseases, unemployment and other social ills. Nigeria needs to design intervention programs that will help in reducing population growth rate and stimulate rapid socioeconomic development. In line with the Government realization of the Millennium Development Goals (MDGs), Government should create enabling environment that will facilitate savings, investment, innovation, entrepreneurship and technical knowhow through a well developed National Population Policy. Truly, efficient national population policy is the strategic horizon that Nigeria must pursue today with all her energy. This has nothing to do with pessimism. Our challenge of controlling our population is nothing less than the challenge of preventing our nation (Nigeria) from being the first victim of the Malthusian prophecy.

\section{References}

1. United Nations (2009) World Urbanization Prospects: The 2009 Revision. Population Division of the Department of Economic and Social Affairs of the United Nations Secretariat; New York: United Nations.

2. United Nations (2012) World Population Prospects: The 2012 Revision: Population Division of the Department of Economic and Social Affairs of the United Nations Secretariat

3. CIA (2009) World Factbook: Nigeria.

4. Ross ML (2003) Nigeria's Oil Sector and the Poor. Paper prepared for the UK Department of International Development 'Nigeria: Drivers of Change' program.

5. Akpan W (2006) Between responsibility and rhetoric: some consequences of CSR practice in Nigeria's oil province. Development Southern Africa 23: 2.

6. Okonjo Iweala N (2005) why Nigeria deserves debt relief. Publication of Federal Ministry of Finance, Nigeria, p. 1-4.

7. World Bank/DFID (2005) Country Partnership Strategy for the Federal Republic of Nigeria. 
8. Clement EP (2011) Financial statistics and debt relief: the Nigeria Perspective. Journal of Science and Technology Research 10(1): 21-26.

9. National Population Commission (NPC)-Nigeria, ICF Macro (2008) Nigeria Demographic and Health Survey (DHS). Abuja, Nigeria: National Population Commission and ICF Macro.

10. National Population Commission (NPC) Nigeria (2006) Population and Housing Census of the Federal Republic of Nigeria. Abuja, Nigeria: National Population Commission.

11. Enaohwo JO (1983) Resource distribution in Nigerian secondary schools: issues of urban-rural inequality. Educational Review 35(1): 25-33.

12. UNESCO (2000) Education for All: The Year 2000 Assessment: Nigeria Country Report.

13. Montgomery M, Stren R, Cohen B, Reed H (2003) Cities Transformed: Demographic Change and Its Implications in the Developing World. DC: National Academies Press, Washington, USA.

14. Mberu B (2005) Who moves and who stays? Rural out-migration in Nigeria. Journal of Population Research 22(2): 141-161.

15. Chen N, Valente P, Zlotnik H (1998) What do we know about recent trends in urbanization? In: Bilsborrow RE, et al. (Eds.), Migration, Urbanization and Development: New Directions and Issues. Norwell, MA: UNFPA-Kluwer Academic Publishers, USA pp. 59-88.

16. Potts D (1995) Shall we go home? Increasing urban poverty in African cities and migration processes. Geographical Journal 161(3): 245-264.
17. Potts D (2000) Urban unemployment and migrants in Africa: Evidence from Harare 1985-1994. Development and Change 31: 879-910.

18. Potts D (2012) Challenging the myths of urban dynamics in subSaharan Africa: The evidence from Nigeria. World Development 40(7): 1382-1393.

19. Bocquier P (2003) Analyzing urbanization in Africa. In: Hugo G, et al. (Eds.), New Forms of Urbanization, Aldershot: Ashgate pp. 133-150.

20. Bocquier P (2005) World urbanization prospects: An alternative to the UN model of projection compatible with urban transition theory. Demographic Research 12(9): 197-236.

21. Bocquier P, Mukandila AK (2011) African urbanization trends and prospects. African Population Studies 25(2): 337-361.

22. Duranton G (2014) Growing Through Cities in Developing Countries, March 2014, World Bank Research Observer, Policy Working Paper No 6818.

23. Gupta CB (1982) An Introduction to Statistical Methods, Vikas Publishing House, New Delhi, India.

24. Ber A, Sachs J (1988) The debt crisis structural explanations of country performance. Journal of Development Economics 29: 271-306.

25. Boeninger E (1991) Governance and Development: Issues and Constraints. In Proceedings of the World Bank Annual Conference on Development Economics: Washington, DC, USA.

\section{Your next submission with Juniper Publishers} will reach you the below assets

- Quality Editorial service

- Swift Peer Review

- Reprints availability

- E-prints Service

- Manuscript Podcast for convenient understanding

- Global attainment for your research

- Manuscript accessibility in different formats

( Pdf, E-pub, Full Text, Audio)

- Unceasing customer service

Track the below URL for one-step submission https://juniperpublishers.com/online-submission.php 